\title{
Minat Belajar Siswa dengan Variasi Penggunaan Media Pembelajaran (Survey pada Siswa Jurusan Akuntansi di SMK Negeri 3 Bandung)
}

\author{
Leni Maryani ${ }^{1}$, Veri Aryanto Sopiansah ${ }^{2}$ \\ Pendidikan Ekonomi, Fakultas Keguruan dan Ilmu Pendidikan, Universitas Pasundan ${ }^{l}$ \\ lenimaryanieunpas.ac.id \\ veriaryanto@gmail.com
}

\begin{abstract}
The purpose of this study was to determine (1) how perceptions of students about the variety of instructional media, (2) the effect of variations in the use of instructional media on student interest accounting department at SMK Negeri 3 Bandung. The method used is survey with a student sample of the accounting department at SMK Negeri 3 Bandung. Analysis of the data used is the analysis of the data verification through calculation of average (mean) score for solving the first problem. As for solving the problem are both used a simple linear regression analysis. Results of research on the variations of the use of learning media can be summed variety of instructional media usage "Very Good" and indicators of a questionnaire on perceptions it is best to use video media. Based on regression analysis indicated by the coefficient of determination R Square, it can be stated that this hypothesis can be accepted. This means that there are significant variations in the use of instructional media on student interest. If you have students who are likely to have the characteristics of a passive, teachers should use the media interesting and varied learning related to the subject matter to be delivered.
\end{abstract}

Keywords -Variation Use of Media Education and Student Learning Interests

\begin{abstract}
Abstrak - Tujuan dari penelitian ini adalah untuk mengetahui (1) bagaimana persepsi siswa mengenai variasi media pembelajaran, (2) pengaruh variasi penggunaan media pembelajaran terhadap minat belajar siswa jurusan akuntansi di SMK Negeri 3 Bandung. Metode penelitian yang digunakan adalah survey dengan sampel siswa jurusan akuntansi di SMK Negeri 3 Bandung. Analisis data yang digunakan adalah analisis verifikatif data melalui perhitungan rata-rata (mean) skor untuk memecahkan masalah pertama. Sedangkan untuk memecahkan masalah yang kedua digunakan analisis regresi linear sederhana. Hasil penelitian mengenai variasi penggunaan media pembelajaran dapat disimpulkan variasi penggunaan media pembelajaran "Sangat Baik" dan indikator kuisioner yang mendapatkan persepsi paling baik adalah penggunaan media video. Berdasarkan analisis regresi yang ditunjukan dengan nilai koefisien determinasi R Square, dapat dinyatakan bahwa hipotesis dalam penelitian ini dapat diterima. Artinya terdapat pengaruh variasi penggunaan media pembelajaran terhadap minat belajar siswa. Jika memiliki siswa yang cenderung memiliki karakteristik pasif, guru sebaiknya menggunakan media pembelajaran yang menarik dan variatif berkaitan dengan materi pelajaran yang akan disampaikan.

Kata Kunci - Variasi Penggunaan Media Pembelajaran dan Minat Belajar Siswa
\end{abstract}




\section{PENDAHULUAN}

Salah satu faktor yang menentukan kualitas pendidikan adalah penyelenggaraan pembelajaran yang dirancang secara sistematis sesuai dengan prinsip-prinsip pembelajaran yang efektif. Karena belajar adalah suatu sistem, maka desain pembelajaran harus dilakukan secara sistematis (menggunakan pendekatan sistem), faktor keberhasilan proses pembelajaran dapat ditentukan oleh minat belajar siswa, minat sebagai pernyataan psikis yang menunjukkan adanya pemusatan perhatian terhadap suatu materi pelajaran karena obyek tersebut menarik bagi dirinya. Minat belajar adalah kecenderungan hati yang tinggi terhadap suatu gairah keinginan untuk suatu perubahan yang terjadi pada seseorang dalam melaksanakan kegiatan (belajar). Minat sangat tergantung pada kapasitas yang dimiliki. Pemusatan perhatian dalam proses pembelajaran sangat diperlukan, karena kehadiran minat belajar dalam pribadi seseorang akan merangsang keinginan untuk belajar yang lebih besar [1].

Kondisi belajar-mengajar yang efektif adalah adanya minat dan perhatian siswa dalam belajar, minat merupakan suatu sifat yang cenderung menetap pada diri seseorang [2].

Minat adalah kecenderungan yang menetap untuk memperhatikan beberapa aktifitas. Seseorang yang berminat terhadap suatu aktifitas akan memperhatikan aktifitas itu secara konsisten. Minat belajar dapat diartikan sebagai ketertarikan terhadap belajar yang menaruh perhatian pada suatu pelajaran tertentu dan disertai hasrat untuk mengetahui, mempelajari, dan membuktikannya melalui partisipasi aktif dalam kegiatan belajar [2] Minat adalah perasaan senang dan tertarik pada suatu obyek, dan cenderung untuk memperhatikan dan akhirnya aktif berkecimpung dalam obyek tersebut [3].

Minat besar sekali pengaruhnya terhadap belajar. Siswa yang mempunyai minat yang tinggi, akan menaruh perhatian yang lebih terhadap pelajaran. Melihat betapa pentingnya minat belajar siswa untuk mendukung proses pembelajaran yang baik, maka peneliti coba mencari data mengenai minat belajar siswa melalui observasi dengan menggunakan lembar observasi. Adapun hasil observasinya sebagai berikut:

TABEL 1

PERSENTASE MINAT BELAJAR SISWA JURUSAN AKUNTANSI DI SMKN 3 BANDUNG

\begin{tabular}{cccc}
\hline No & $\begin{array}{c}\text { Indikator } \\
\text { Minat Belajar }\end{array}$ & $\begin{array}{c}\text { Frekuensi } \\
\text { (orang) }\end{array}$ & $\begin{array}{c}\text { Persentase } \\
(\%)\end{array}$ \\
\hline
\end{tabular}

\begin{tabular}{cccc}
\hline 1 & Kesukaan & 2 & $16,7 \%$ \\
2 & Ketertarikan & 3 & $25 \%$ \\
3 & Perhatian & 4 & $33,3 \%$ \\
4 & Keterlibatan & 3 & $25 \%$ \\
\hline & Jumlah & $\mathbf{1 2}$ & $\mathbf{1 0 0 \%}$ \\
\hline
\end{tabular}

Sumber: hasil observasi jurusan akuntansi SMKN

3 Bandung

Dari tabel di atas terdapat 2 orang yang merasa senang, 3 orang yang tertarik dalam pembelajaran, 4 orang yang memperhatikna dalam pembelajaran dan 3 orang yang ikut terlibat, dimana seluruh siswa jurusan akuntansi terdapat 38 orang. Dapat disimpulkan bahwa hanya 12 orang yang mempunyai minat belajar sedangkan 26 orang tidak menunjukan minat dalam pembelajaran.

Adanya variasi penggunaan media pembelajaran diharapkan dapat menumbuhkan minat belajar siswa sehingga siswa tidak mengalami kejenuhan dalam mengikuti kegiatan pembelajaran di dalam kelas. Penggunaan media yang tepat dalam pembelajaran juga dapat mengembangkan seluruh potensi yang terdapat dalam diri siswa secara optimal baik kognitif, afektif maupun psikomotorik [3].

Disamping mampu menggunakan alatalat yang tersedia, guru juga dituntut untuk dapat mengembangkan keterampilan membuat media pembelajaran yang akan digunakan apabila media tersebut belum tersedia, untuk itu guru harus memiliki pengetehuan dan pengalaman yang cukup tentang media pembelajaran [4].

Cara meningkatkan hasil belajar siswa, yaitu siswa harus memiliki minat terlebih dahulu sebelum mengikuti proses pembelajaran, agar proses pembelajaran berjalan dengan baik salah satu cara membangkitkan minat adalah menggunakan variasi media dalam pembelajaran. Variasi media pembelajaran sudah terbukti dapat membangkitkan minat belajar siswa dalam pembelajaran [5].

Hal ini dilakukan sebagai salah satu cara untuk menarik minat siswa dalam memperhatikan atau proses pembelajaran, selain itu juga guru dapat melihat hasil akhir dari proses pembelajaran dalam bentuk peningkatan nilai setelah dievaluasi. Pengunaan internet merupakan teknologi yang sekarang ini sedang berkembang yang bisa diambil manfaatnya dalam memperoleh 
informasi berkaitan dengan bidang pendidikan. Informasi tersebut dapat dikemas dalam media pembelajaran [6]

Untuk mengetahui berapa besar minat belajar siswa, dapat diukur melalui [8]:

1. Kesukaan, pada umumnya individu yang suka pada sesuatu disebabkan karena adanya minat. Biasanya apa yang paling disukai mudah sekali untuk diingat. Sama halnya dengan siswa yang berminat pada suatu mata pelajaran tertentu maka akan menyukai dan mudah untuk mengingat pelajaran tersebut.

2. Ketertarikan, seringkali dijumpai beberapa siswa yang merespon dan memberikan reaksi terhadap apa yang disampaikan guru pada saat proses belajar mengajar di kelas.

3. Perhatian, semua siswa yang mempunyai minat terhadap pelajaran tertentu akan cenderung memberikan perhatian yang besar terhadap pelajaran itu.

4. Keterlibatan yakni keterlibatan, keuletan, dan kerja keras yang tampak melalui diri siswa menunjukkan bahwa siswa tersebut ada keterlibatannya dalam belajar dimana siswa selalu belajar lebih giat, berusaha menemukan hal-hal yang baru yang berkaitan dengan pelajaran yang diberikan guru di sekolah.

Minat seseorang tidak timbul secara tibatiba. Faktor-faktor yang memperngaruhi belajar ada dua macam, yaitu faktor intern dan ekstern [9]. Faktor intern menurutnya lebih mengarah kepada kondisi jasmaniah siswa seperti kesehatan, perhatian, minat, bakat, kematangan, kesiapan, dan kelelahan. Faktor ekstern berupa faktor keluarga, sekolah, masyarakat. Faktor sekolah berupa kurikulum, relasi guru dan siswa, keadaan gedung sekolah, metode dan media mengajar. Penggunaan media yang sesuai dengan materi pelajaran dapat mendorong minat belajar sehingga dapat mencapai tujuan pembelajaran [3].

Pengembangan variasi mengajar merupakan upaya terencana dengan berbagai komponen yang mampu mempengaruhi pembelajaran. Variasi adalah alah satu cara yang membuat siswa tetap konsentrasi dan termotivasi, sehingga kegiatan pembelajaran senantiasa berjalan dengan dinamis [7]. Variasi media pembelajaran adalah penggunaan media secara bervariasi antara jenis-jenis media belajar yang ada. Akan tetapi, penggunaannya tidak lepas dari pertimbangan tujuan belajar yang akan dicapai [10].

Ada tiga variasi dalam penggunaan media, yaitu media pandang, media dengar, dan media taktil [11].

1. Variasi Media Pandang. Penggunaan media pandang dapat diartikan sebagai penggunaan alat dan bahan ajaran khusus untuk komunikasi seperti buku, majalah, peta, globe, dan lain-lain.

2. Variasi Media Dengar. Variasi dalam media dengar memerlukan kombinasi dengan media pandang dan media taktil. Media dengar yang dapat dipakai diantaranya pembicaraan anak didik, rekaman bunyi suara, wawancara, yang memiliki relevansi dengan pelajaran.

3. Variasi Media Taktil. Media taktil adalah media yang memberikan kesempatan kepada anak didik untuk menyentuh dan memanipulasi benda atau bahan ajar dalam bentuk model.

Salah satu faktor yang mempengaruhi minat belajar adalah pemanfaatan media pembelajaran. Media adalah komponen sumber belajar atau wahana fisik yang mengandung materi instruksional dilingkungan siswa, yang dapat merangsang siswa untuk belajar, media pembelajaran dalam proses belajar mengajar dapat membangkitkan keinginan dan minat yang baru, membangkitkan motivasi dan rangsangan kegiatan belajar, bahkan membawa pengaruh-pengaruh psikologis terhadap siswa [5].

Pengelompokan berbagai jenis media pembelajaran [12]:

1. Media berbasis manusia (guru, instruktur, tutor, main peran, kegiatan kelompok, fieldtrip).

2. Media berbasis cetak (buku, penuntun, buku latihan, alat bantu kerja, dan lembaran kertas).

3. Media berbasis visual (buku, charta, grafik, peta, gambar, transparansi, slide).

4. Media berbasis audio-visual (video, film, program slide tape, televisi).

5. Media berbasis komputer (pengajaran dengan berbantuan komputer, video interaktif, hypertext).

Berdasarkan latar belakang dan kajian teori maka rumusan masalah dalam penelitian ini yaitu: (1) Bagaimana persepsi siswa mengenai variasi media pembelajaran? (2) Apakah terdapat pengaruh variasi penggunaan media pembelajaran terhadap minat belajar 
siswa jurusan akuntansi di SMK Negeri 3 Bandung?

Serta dirumuskan hipotesis yaitu terdapat pengaruh variasi penggunaan media pembelajran terhadap minat belajar siswa.

\section{METODOLOGI PENELITIAN}

Metode penelitian yang digunakan adalah metode survey dengan tujuan ingin melihat bagaimana kejadian-kejadian berlangsung pada waktu tertentu terjadi dan adakah dampaknya pada kejadian yang lain. Desain penelitian ini berjenis crossectional desain (penelitian jangka pendek) secara sederhana dilakukan dengan langkah (1) mengidentifikasi fenomena dan memilih masalah yang kemudian dijadikan variabel $\mathrm{Y}$ (minat belajar siswa); (2) Peneliti memilih variasi penggunaan media pembelajaran sebagai variabel $\mathrm{X}$ untuk mengatasi masalah penelitian; (3) Peneliti memberikan asumsi dan hipotesis untuk diuji bahwa terdapat pengaruh variasi penggunaan media pembelajaran $(\mathrm{X})$ terhadap minat belajar siswa (Y); (4) membangun penyelidikan atau percobaan dengan metode survey; (5) memilih teori-teori dari para ahli mengenai variable $\mathrm{X}$ variasi media pembelajaran dan variable $\mathrm{Y}$ minat belajar siswa; (6) sampel dalam penelitian ini yaitu siswa kelas $\mathrm{X}$ jurusan akuntansi yang berjumlah 38 siswa; (7) menggunakan angket sebagai teknik penggumpulan data; (8) melakukan uji hipotesis guna menjawab rumusan masalah yang telah ditetapkan; (9) melaporkan hasil penelitian.

Adapun rumusan operasionalisasi variabel sebagai berikut:

TABEL 2

OPERASIONALISASI VARIABEL

\begin{tabular}{|c|c|}
\hline \multicolumn{2}{|r|}{ Variabel X } \\
\hline Dimensi & Indikator \\
\hline $\begin{array}{c}\text { Variasi Media } \\
\text { Ajar }\end{array}$ & Jenis Media Pembelajaran \\
\hline 1. Media dengar & $\begin{array}{l}\text { 1. Media berbasis audio-visual } \\
\text { - Film } \\
\text { - Video } \\
\text { - Media televisi } \\
\text { 2. Media berbasis visual } \\
\text { - Media berita } \\
\text { - Media wawancara }\end{array}$ \\
\hline 2. Media pandang & $\begin{array}{l}\text { 3. Media cetak } \\
\text { - Media makalah } \\
\text { - Media buku } \\
\text { - Media koran } \\
\text { - Media artikel } \\
\text { - Media gambar }\end{array}$ \\
\hline
\end{tabular}

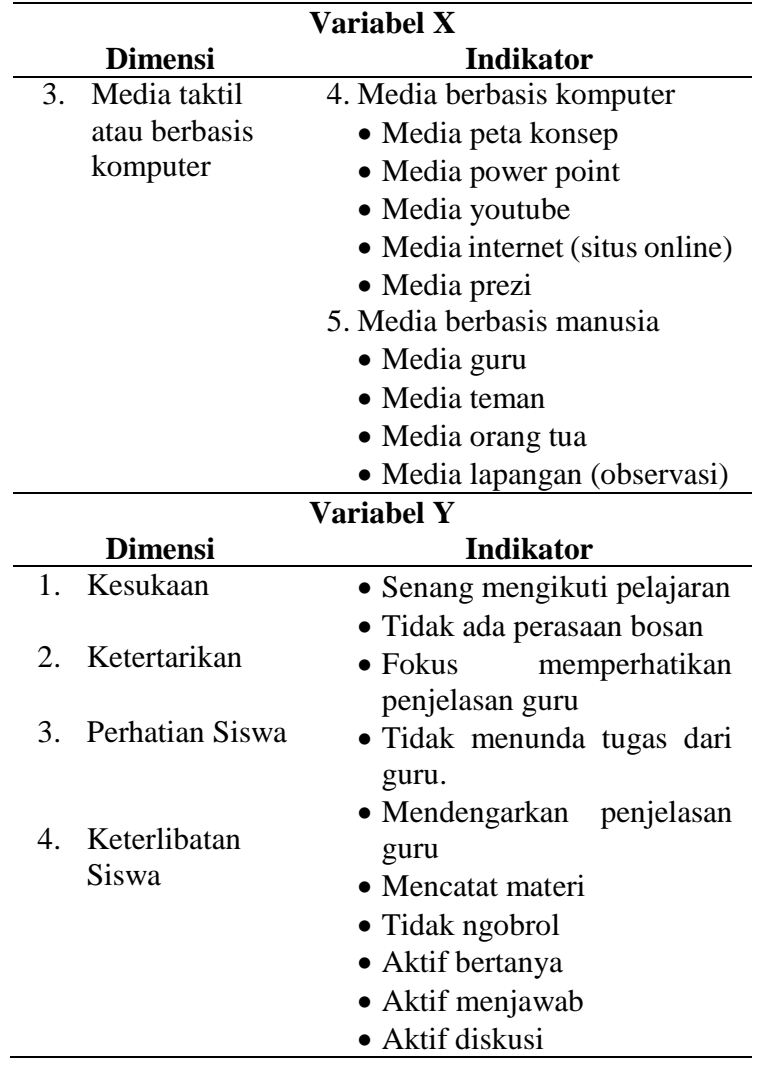

Penulis meggunakan skala likert dengan pemberian skor yang ditentukan pada setiap butir pertanyaan/pernyataan angket. Penskoran didasarkan pada skala likert dimana setiap option terdiri dari lima kategori yang diberi skala (1) sangat tidak baik (2) tidak baik (3) cukup (4) baik (5) sangat baik.

Setelah data terkumpul, dilakukan pengujian instrument penelitian berupa uji validitas dan uji reliabilitas. Selanjutnya melakukan uji analisis data (uji hipotesis) dengan rancangan (1) uji normalitas data (2) analisis verivikatif data (mean) (3) uji regresi (4) pembahasan hasil penelitian.

\section{HASIL PENELITIAN DAN PEMBAHASAN}

Data hasil perhitungan seluruh butir instrumen pada pertanyaan angket variabel $X$ (19 item) dan variabel Y (10 item) dinyatkan valid. Dari pengujian reliabilitas, varibel $\mathrm{X}$ memiliki reliabilitas sebesar 0,889 dan varibel Y sebesar 0,816, maka data tersebut menunjukan klasifikasi sangat reliable. Hasil uji normalitas, variabel yang telah di uji berdistribusi normal dengan nilai signifikasi $200^{*}$.

a. Persepsi Siswa Mengenai Variasi Media Pembelajaran dan Minat Belajar Siswa 
Berdasarkan hasil analisis menunjukkan bahwa rata-rata item pertanyan tentang variasi penggunaan media pembelajaran adalah "Sangat Baik" ditunjukkan dengan rata-rata bobot sebesar 4,02. Dari sekian banyak jenis media pembalajaran yang paling sering digunakkan guru, dibuatlah angket yang disebarkan kapada 38 siswa untuk memberikan persepsinya mengenai media mana yang paling meningkatkan minat belajarnya. Berdasarkan hasil analisis data, media video yang paling meningkatkan minat belajar siswa. Pembelajaran dengan menggunakan media video berpengaruh signifikan terhadap minat dan hasil, penggunaan video pembelajaran merupakan metode yang sangat luar biasa di tengah kemajuan dan perkembangan teknologi sekarang ini [6].

Berdasarkan hasil analisis menunjukkan bahwa rata-rata item pertanyan tentang minat belajar siswa adalah "Sangat Baik" ditunjukkan dengan rata-rata bobot sebesar 4,01. Persepsi minat belajar siswa sangat baik disebabkan oleh variasi penggunaan media pembelajaran memberikan perasaan senang dalam belajar, memberikan perasaan tidak bosan dalam belajar, meningkatkan kehadiran siswa dalam pembelajaran, memberikan antusisa siswa untuk belajar, lebih mudah mencerna penjelasan dari guru, serta lebih mudah dipahami dan dicatat oleh siswa.

\section{b. Pengaruh Variasi Penggunaan Media Pembelajaran Terhadap Minat Belajar Siswa}

Pada penelitian ini penulis melakukan uji statistik dengan tujuan untuk mencari kecenderungan pengaruh antara variabel $\mathrm{X}$ (variasi penggunaan media pembelajaran) terhadap variabel Y (Minat belajar siswa). Hasil perhitungan regresi linear adalah sebagai berikut:

TABEL 3

ANALISIS REGRESI LINEAR SEDERHANA COEFFICIENTS $^{A}$

\begin{tabular}{|c|c|c|c|c|c|c|}
\hline \multirow[t]{2}{*}{ Model } & & \multicolumn{2}{|c|}{$\begin{array}{l}\text { Unstandardized } \\
\text { Coefficients }\end{array}$} & \multirow{2}{*}{$\begin{array}{c}\begin{array}{c}\text { Standardized } \\
\text { Coefficients }\end{array} \\
\text { Beta }\end{array}$} & \multirow[t]{2}{*}{$\mathrm{T}$} & Sig \\
\hline & & B & $\begin{array}{c}\text { Std. } \\
\text { Error }\end{array}$ & & & \\
\hline \multirow{2}{*}{1} & $\begin{array}{l}\text { (Constan } \\
\text { t) }\end{array}$ & 4.430 & 4.391 & & 1.009 & \\
\hline & Total_X & .467 & .057 & .806 & 8.179 & \\
\hline
\end{tabular}

a. Dependent Variable: Total_Y

Sumber: Hasil Pengolahan Data Program SPSS 21,0 for windows
Berdasarkan hasil perhitungan regresi yang tertera pada tabel di atas, maka dapat dibentuk persamaan regresi linier sederhana sebagai berikut:

$$
Y=4,430+0.467 X
$$

Dimana: $\mathrm{Y}=$ Minat Belajar

$\mathrm{X}=$ Variasi Media pembelajaran

Berdasarkan tabel perhitungan di atas, dapat dilihat bahwa angka konstan sebesar 4,430 yang dapat diartikan minat belajar siswa tanpa penggunaan variasi media pembelajaran senilai 4,430. Sedangkan koefisien regresi menunjukan nilai 0,467 yang dapat diartikan ketika guru menggunakan media pembelajaran senilai $1 \%$ maka akan meningkatkan minat belajar siswa senilai 0,467 . Melihat hasil dari analisis regresi linear sederhana maka dapat diuji hipotesisnya dengan membandingkan nilai $\mathrm{t}$ hitung dengan $\mathrm{t}$ tabel, karena dalam penelitian ini nilai $\mathrm{t}$ hitung lebih besar dari $\mathrm{t}$ tabel maka dapat diisimpulkan hipotesis diterima, yang berarti terdapat pengaruh variasi penggunaan media pembelajaran terhadap minat belajar siswa. Selanjutnya menghitung koefisien determinasi yang digunakan untuk mengukur besarnya pengaruh variasi penggunaan media pembelajaran terhadap minat belajar. Berikut hasil perhitungannya :

\section{TABEL 4}

BESAR PENGARUH $X$

TERHADAP Y MODEL SUMMARY ${ }^{b}$



Berdasarkan tabel di atas diperoleh angka $\mathrm{R}$ sebesar 0,806. Besar kontribusi yang diberikan oleh variabel variasi penggunaan media pembelajaran dilihat dari $\mathrm{R}$ Squere sebesar 0,650 hal ini menunjukan bahwa sig.pengaruh variasi penggunaan media pembelajaran sebesar $65 \%$ terhadap minat belajar siswa, berarti variasi penggunaan media pembelajaran memiliki pengaruh "baik" 32 (erhadap minat belajar siswa. Berdasarkan perhitungan koefisien determinasi diketahui .09hinat belajar siswa dipengaruhi oleh variasi penggunaan media pembelajaran sebesar $65 \%$ sebagian lainnya 35\% dipengaruhi oleh faktor lain di luar variasi penggunaan media 
pembelajaran, seperti guru, lingkungan sekolah dan lainnya.

Pengaruh variasi penggunaan media pembelajaran terhadap minat belajar siswa sebesar $65 \%$. Hasil penelitian dapat diketahui bahwa variasi penggunaan media pembelajaran dapat meningkatkan minat belajar siswa. Penggunaan variasi media pembelajaran memiliki pengaruh positif terhadap minat belajar, dimana semakin sering digunakan media pembelajaran maka minat belajar siswa semakin meningkat, penggunaan variasi media lebih baik dibanding tidak menggunakan media [5]. Pemanfaatan media pembelajaran berpengaruh positif dan signifikan terhadap minat belajar siswa [7]. Hal ini dapat digunakan sebagai bahan pertimbangan bagi guru untuk menerapkan media pembelajaran yang bervariasi dalam pembelajaran yang disesuaikan dengan materi pembelajaran. Untuk meningkatkan minat belajar siswa, pendidik dapat menerapkan berbagai media pembelajaran yang inovatif dan menyenangkan siswa sehingga dapat meningkatkann minat belajarnya.

Dari hasil penjelasan di atas, variasi penggunaan media pembelajaran telah diterapkan dengan baik dan berpengaruh baik terhadap minat belajar siswa di jurusan akuntansi di SMK Negeri 3 Bandung.

Semakin baik kualitas penggunaan media pembelajaran akan semakin baik minat belajar siswa.

\section{KESIMPULAN, SARAN DAN IMPLIKASI}

\section{a. Kesimpulan}

Berdasarkan hasil analisis data dan pengujian hipotesis yang dilakukan peneliti di SMK Negeri 3 Bandung mengenai pengaruh variasi penggunaan media pembelajaran terhadap minat belajar siswa, maka ditarik kesimpulan bahwa penerapan variasi penggunaan media pembelajaran telah berlangsung sangat baik.

\section{b. Saran}

Berdasarkan hasil penelitian variasi, maka disampaikan saran sebagai berikut:

1. Siswa harus fokus ketika belajar agar dapat memahami materi pelajaran yang disampaikan, siswa harus dapat mencari berbagai sumber belajar selin dari guru, dan siswa harus dapat meningkatkan kegiatan berdiskusi dengan teman, bertanya apabila tidak mengerti dan saling berbagi pengetahuan sesama teman.

2. Jika guru memiliki siswa yang cenderung memiliki karakteristik pasif, guru sebaiknya menggunakan variasi media pembelajaran yang menarik yang disesuaikan dengan fasilitas dan kemampuan guru dalam menggunakan media tertentu yang berkaitan dengan materi pelajaran yang akan disampaikan karena cara ini dapat membuat siswa lebih berminat untuk belajar.

3. Bagi para praktisi atau peneliti lain di bidang pendidikan dapat melakukan penelitian serupa dengan media pembelajaran dan metode yang berbeda agar diperoleh berbagai alternatif untuk peningkatan pemahaman pembelajaran pada pokok bahasan selanjutnya.

\section{c. Implikasi}

Seiring berkembangnya ilmu pengetahuan dan teknologi maka semakin banyak tuntutan yang melekat pada seorang guru, apalagi teknologi sangat mendukung sekali penggunaan media pembelajarn, maka dari itu guru diharuskan memiliki kemampuan untuk menggunakan teknologi yang dapat dijadikan media pembelajaran unuk mendukung Pendidikan abad 21, hal ini dirasa perlu dilakukan karena dengan menggunakan variasi media pembelajaran terbukti secara empiris dapat meningkatkan minat belajar siswa, sedangkan banyak kajian yang dilakukan bahwa minat belajar besar pengaruhnya terhadap hasil belajar siswa. Penggunaan media pembeljaran harus bervariasi dan tidak hanya menggunakan satu jenis saja karena dapat menimbulkan hal yang tidak baik juga, seperti adanya rasa bosan karena guru terlalu sering menggunakan hal tersebut, maka dari itu diperlukan suatu skill untuk menggunakan media pembelajaran.

\section{DAFTAR PUSTAKA}

[1] N. D. Muldayanti. (2013). Pembelajaran Biologi Model Stad Dan Tgt Ditinjau Dari Keingintahuan Dan Minat Belajar Siswa. JPII, 1(1), 12-17. https://doi.org/10.15294/jpii.v4i2.41

[2] H. Kartika, "PEMBELAJARAN MATEMATIKA BERBANTUAN SOFTWARE MATLAB SEBAGAI UPAYA MENINGKATKAN KEMAMPUAN KOMUNIKASI MATEMATIS DAN MINAT BELAJAR SISWA SMA" $J$. Pendidik. UNSIKA, vol. 2, no. November, pp. 24 35, 2014.

[3] N. Arifani, "PENGARUH PENGGUNAAN FLIP CHART SEBAGAI MEDIA PEMBELAJARAN SEJARAH TERHADAP MINAT BELAJAR SISWA KELAS X IPA MADRASAH ALIYAH NEGERI 1 CIREBON TAHUN AJARAN 20142015," Univ. Negeri Semarang, 2015.

[4] K. Anam, "PENGARUH MEDIA PEMBELAJARAN TERHADAP MINAT BELAJAR SISWA PADA MATA PELAJARAN PAI DI SMP BANI MUQIMAN BANGKALAN," J. Pendidik. Islam, vol. 4, no. 2, 2015.

[5] Etimar, "PENGARUH VARIASI MEDIA VIDEO 
TERHADAP MINAT BELAJAR SISWA," $J$.

Pendidik. Guru Sekol. Dasar, vol. 6, no. 4, 2017.

[6] S. S. Viviantini, Amram Rede, "Pengaruh Media Video Pembelajaran Terhadap Minat Dan Hasil Belajar Ipa Siswa Kelas Vi Sdn 6 Kayumalue

Ngapa," J. Sains dan Teknol. Tadulako, vol. 4, no. 1, pp. 66-71, 2015.

[7] L. N. H. Marfuah, "PENGARUH VARIASI MENGAJAR GURU DAN PEMANFAATAN MEDIA PEMBELAJARAN TERHADAP MINAT BELAJAR IPS TERPADU SISWA KELAS VII DI MTSN SURAKARTA II," Univ Muhammadiyah Surakarta, 2015. I

[8] Herlina, Minat Belajar, Jakarta: Bumi Aksara, 2010.

[9] Slameto, Belajar dan Faktor-Faktor yang Mempengaruhinya, Jakarta: Rineka Cipta, 2013.

[10] M. Idris, Strategi dan Metode Pengajaran, Jogjakarta : Ar-Ruzz. Media. Medinat F. Salman., 2009.

[11] S. B. Djamarah, Psikologi Belajar, Jakarta: Rineka Cipta, 2002.

[12] A. Arsyad, Media Pembelajaran, Jakarta : PT Rajawali Press, 2011. 
